\title{
Abundance of viruses in deep oceanic waters
}

\author{
Seiko Hara $^{1, *}$, Isao Koike ${ }^{2}$, Kazuki Terauchi $^{2}$, Hitomi Kamiya $^{3}$, Eiichiro Tanoue ${ }^{4}$ \\ 'Department of Marine Resources, National Sun Yat-sen University, Kaohsiung, Taiwan 80424, Republic of China \\ ${ }^{2}$ Ocean Research Institute, University of Tokyo, Nakano, Tokyo 164, Japan \\ ${ }^{3}$ Japan Meteorological Agency, Otemachi 1-3-4, Chiyoda-ku, Tokyo 100, Japan \\ 4Meteorological Research Institute, 1-1, Nagamine, Tsukuba-shi 305, Japan
}

\begin{abstract}
Vertical distributions of bacteria and viruses were investigated in the oceanic stations located in subarctic (Stn A) and subtropical (Stn B) areas of the Pacific using the direct count technique and transmission electron microscopy. Small DAPI-positive, virus-like particles (VLP) were found to be distributed throughout the water column down to $5000 \mathrm{~m}$ at both of the stations. The abundance of VLP ranged from $38 \times 10^{5} \mathrm{ml}^{-1}$ at $50 \mathrm{~m}$ depth to $0.6 \times 10^{5} \mathrm{ml}^{-1}$ at $5000 \mathrm{~m}$ depth at Stn $\mathrm{A}$. The ratio of VLP to bacteria-like particle (BLP) ranged from 1.1 to 7.4 at Stn A and 1.0 to 8.7 at Stn B in the entire water column. The maximum ratio was recorded at $S \mathrm{tn} B$ from the deepest sample, collected at a depth of $5000 \mathrm{~m}$. The electron microscopic investigation indicated that the major proportion of VLP were probably viruses.
\end{abstract}

KEY WORDS: Virus Bacteriophage Bacteria Deep water Oceanic water

\section{INTRODUCTION}

Viruses are recognized as important members of the marine surface water ecosystem due to their role as decomposers of bacterial and protistan biomasses (Suttle et al. 1990, Bratbak et al. 1992, Wommack et al. 1992, Cochlan et al. 1993, Jiang \& Paul 1994, Murray \& Eldridge 1994). Recently, various techniques have been developed for detecting viruses in marine environments (Bergh et al. 1989, Proctor \& Fuhrman 1990, Hara et al. 1991). Most of them come to similar conclusions, that viruses are present at concentrations up to $10^{8} \mathrm{ml}^{-1}$ in coastal waters, up to $10^{7} \mathrm{ml}^{-1}$ in offshore waters, and up to $10^{6} \mathrm{ml}^{-1}$ in oceanic waters. The abundances of bacteria are approximately $10^{7}, 10^{6}$ and $10^{5}$ cells $\mathrm{ml}^{-1}$ for the coastal, offshore and oceanic waters, respectively.

These observations, however, are limited to surface waters. Current knowledge regarding bacterial distribution and activity in the deep sea is limited, but indicates the abundance of bacteria with some activities in

\footnotetext{
- Present address: Miyazaki International College, 1405 Kano, Kiyotake-cho, Miyazaki 889-16, Japan.

E-mail·shara@kokusai.miyazakı-mic.ac.jp
}

that environment (Patterson et al. 1993, Turley and Mackie 1994, I. Koike \& T. Nagata unpubl.). There is no information available on the occurrence and characteristics of viruses in deep water

The concentration of viruses is essential information for the ecological study of the aquatic environment. Three major methods have been applied to enumerating virus particles: an ultracentrifugation concentrationTEM (transmission electron microscopy) observation process (Bergh et al. 1989), an ultrafiltration concentration-TEM observation process (Proctor \& Fuhrman 1990), and a filtration-epifluorescent microscope observation process (Hara et al. 1991). The concentration-TEM observation processes have the advantage that one can observe the morphology of virus particles, however, these processes are time consuming and require specialized equipment, e.g. TEM, ultracentrifuge. The filtration-epifluorescent microscope observation technique, on the other hand, is an easily handled and time saving process, requiring only an epifluorescent microscope in addition to normal laboratory equipment. This technique, however, has an ambiguity in distinguishing bacteria from viruses.

In the present study, the reliability of the filtrationepifluorescent microscope observation technique will 
be established. In addition, the vertical distributions of viruses and bacteria are reported for the first time for waters collected from the surface to $5000 \mathrm{~m}$ depth. Finally, a comparison is made of the distribution profiles for 2 stations located in the subtropical and subarctic areas of the North Pacific Ocean.

\section{MATERIALS AND METHODS}

Seawater samples were collected from 2 oceanic stations (subarctic Stn $\mathrm{A}$, at $44^{\circ} 59.780^{\prime} \mathrm{N}, 165^{\circ} 08.989^{\prime} \mathrm{E}$, on 13 May 1991 and subtropical Stn B, at $24^{\circ} 59.730^{\circ} \mathrm{N}$, $164^{\circ} 59.799^{\prime} \mathrm{E}$, on 19 May 1991) at varying depths in the North Pacific with a Niskin water sampler during cruise KH-91-3 of the RV 'Hakuho-Maru'. Immediately after sampling, seawater samples were fixed with formalin (final conc. $1 \%, v / v$ ), that had been pre-filtered by a disk filter (pore size $0.2 \mu \mathrm{m}$ ). For enumeration of bacteria and virus particles, samples were stained with DAPI and then filtered and mounted on glass slides with immersion oil on board (within 1 d) for later measurements ashore with the epifluorescence light microscopy (ELM method) (Hara et al. 1991). The filter sample preparations for enumeration were stored in a deep-freezer under dark and dry conditions.

Total bacteria and viruses were enumerated by counting the number of fluorescing particles on the $0.015 \mu \mathrm{m}$ pore size Nuclepore filter under the photomicrograph (film count; Hara et al. 1991). Small and dimly fluorescing particles (Sieracki \& Viles 1992), smaller than $0.2 \mu \mathrm{m}$ were considered as virus-like particles (VLP), while large and brightly fluorescing particles larger than $0.2 \mu \mathrm{m}$ were considered as bacteria-like particles (BLP). The sizes of fluorescing particles are given as the length of the long axis of the particles. The abundance of bacteria determined by film count was cross-checked with that obtained by direct count using filters of different pore sizes and materials $10.2 \mu \mathrm{m}$ Poretics polycarbonate filter which is equivalent to $0.2 \mu \mathrm{m}$ Nuclepore, $0.2 \mu \mathrm{m}$ Anodisc aluminosilicate filter, $0.02 \mu \mathrm{m}$ Anodisc aluminosilicate filter and $0.015 \mu \mathrm{m}$ Nuclepore polycarbonate filter). Coastal sea water collected from southern Taiwan (Nan-Wan, 15 November 1993) was used for this evaluation. Almost no VLP, less than $1 \%$ of the VLP count with the $0.015 \mu \mathrm{m}$ Nuclepore filter, were observed in blanks of the pre-filtered (0.02 $\mu \mathrm{m}$ Anodisc) sea water

Viruses and bacteria particles can be distinguished on the basis of their mor- phology when examined using TEM. In order to verify the accuracy of the viral abundance measured with the ELM method, viral and bacterial abundances from 4 samples collected from different depths at Stn A were counted with the TEM method as well. In this case, the fixed seawater samples were stored in the refrigerator on board ship. The water samples were dialyzed ashore with a short polyethylene cylinder approximately $3 \mathrm{~mm}$ in height affixed with a $0.015 \mu \mathrm{m}$ Nuclepore filter on both sides, mounted directly on a grid without any concentration, negatively stained by uranyl acetate and observed with a JEOL $200 \mathrm{CX}$ electron microscope as described by Hara et al. (1991).

\section{RESULTS}

\section{Comparison of film counts and direct counts}

The mean $( \pm$ SE) abundance of the BLP (bacteria-like fluorescing particles larger than $0.2 \mu \mathrm{m}$ ) from different depths, filters, and enumeration methods are summarized in Table 1 (depth: 0, 5, 10, and $20 \mathrm{~m}$; filters: $0.2 \mu \mathrm{m}$ Poretics, $0.2 \mu \mathrm{m}$ Anodisc, $0.02 \mu \mathrm{m}$ Anodisc, and $0.015 \mu \mathrm{m}$ Nuclepore; methods: direct and film counts). A 3 -way analysis of variation, filter (4) $\times$ depth (4) $\times$ method (2), was performed. The results indicated that the main effects of depth and method were not significant; however, that of filter was significant, $F_{3,440}=$ 13.784, $\mathrm{p}<0.001$. The mean counts for $0.2 \mu \mathrm{m}$ Poretics, $0.2 \mu \mathrm{m}$ Anodisc, $0.02 \mu \mathrm{m}$ Anodisc, and $0.015 \mu \mathrm{m}$ Nuclepore filters were $4.74,5.51,5.47$, and $5.04 \times 10^{5}$ cells $\mathrm{ml}^{-1}$, respectively. An a posteriori test (Tukey B) at $\mathrm{p}<$

Table 1. Abundances of bacteria and viruses in Nan-wan (Taiwan) samples enumerated with direct and film counts. Cells were collected with different filters; $0.2 \mu \mathrm{m}$ Poretics (P), $0.2 \mu \mathrm{m}$ and $0.02 \mu \mathrm{m}$ Anodısc (A) and $0.015 \mu \mathrm{m}$ Nuclepore $(\mathrm{N})$

\begin{tabular}{|c|c|c|c|c|}
\hline \multirow[t]{2}{*}{ Filter } & \multicolumn{4}{|c|}{ Abundance at each depth $\left(10^{5} \mathrm{ml}^{-1}\right)$} \\
\hline & $0 \mathrm{~m}$ & $5 \mathrm{~m}$ & $10 \mathrm{~m}$ & $20 \mathrm{~m}$ \\
\hline \multicolumn{5}{|c|}{ Bacteria (direct count) } \\
\hline $02 \mu \mathrm{MP}$ & $522 \pm 0.37$ & $5.02 \pm 0.19$ & $4.33 \pm 0.18$ & $4.40 \pm 0.41$ \\
\hline $0.2 \mu \mathrm{m} \mathrm{A}$ & $5.01 \pm 0.07$ & $5.60 \pm 0.17$ & $5.23 \pm 0.23$ & $5.64 \pm 0.27$ \\
\hline $0.02 \mu \mathrm{m} \mathrm{A}$ & $5.30 \pm 0.08$ & $5.42 \pm 0.38$ & $5.82 \pm 0.28$ & $5.54 \pm 0.16$ \\
\hline $0.015 \mu \mathrm{m} \mathrm{N}$ & $4.76 \pm 0.01$ & $5.11 \pm 0.26$ & $5.75 \pm 0.30$ & $4.86 \pm 0.26$ \\
\hline \multicolumn{5}{|c|}{ Bacteria (film count) } \\
\hline $0.2 \mu \mathrm{mP}$ & $4.94 \pm 0.03$ & $4.94 \pm 0.42$ & $4.64 \pm 0.18$ & $4.44 \pm 0.52$ \\
\hline $0.2 \mu \mathrm{m} \mathrm{A}$ & $5.43 \pm 0.30$ & $5.42 \pm 0.20$ & $6.43 \pm 0.31$ & $5.66 \pm 0.42$ \\
\hline $0.02 \mu \mathrm{m} \mathrm{A}$ & $5.86 \pm 0.13$ & $5.04 \pm 0.57$ & $5.91 \pm 1.10$ & $4.99 \pm 0.95$ \\
\hline $0.015 \mu \mathrm{m} \mathrm{N}$ & 4.74 & 4.92 & 5.00 & 4.76 \\
\hline \multicolumn{5}{|c|}{ Viruses (film count) } \\
\hline $0.2 \mu \mathrm{mP}$ & $2.67 \pm 0.43$ & $2.38 \pm 0.21$ & $2.53 \pm 0.27$ & $2.59 \pm 0.20$ \\
\hline $0.2 \mu \mathrm{m} \mathrm{A}$ & $11.37 \pm 4.85$ & 12.76 & $11.23 \pm 3.44$ & $12.92+2.93$ \\
\hline $0.02 \mu \mathrm{m} \mathrm{A}$ & $4.91+0.38$ & $4.43 \pm 0.93$ & $4.55 \pm 1.99$ & $3.27 \pm 0.79$ \\
\hline $0.015 \mu \mathrm{m} \mathrm{N}$ & 21.63 & 18.56 & 17.61 & 17.57 \\
\hline
\end{tabular}


0.05 showed that no significant differences were indicated between (1) $0.2 \mu \mathrm{m}$ Anodisc and $0.02 \mu \mathrm{m}$ Anodisc filter counts, and (2) $0.2 \mu \mathrm{m}$ Poretics and $0.015 \mu \mathrm{m}$ Nuclepore filter counts. However, the bacterial counts with the $0.2 \mu \mathrm{m}$ Poretics and $0.015 \mu \mathrm{m}$ Nuclepore filters differed significantly from those of the $0.2 \mu \mathrm{m}$ Anodisc and $0.02 \mu \mathrm{m}$ Anodisc filters. BLP abundance enumerated by film count on $0.015 \mu \mathrm{m}$ Nuclepore filters (the method adopted in this paper) was equivalent to that obtained by direct count on $0.2 \mu \mathrm{m}$ Poretics filter, which is in accordance with the popular method introduced by Porter \& Feig (1980).

Significant differences were observed in the abundance of VLP (virus-like fluorescing particles smaller than $0.2 \mu \mathrm{m}$ ) enumerated with film counts on different filters. The highest abundance of VLP was found using the filter with the smallest pore size $(0.015 \mu \mathrm{m}$ Nuclepore). Comparing $0.2 \mu \mathrm{m}$ Poretics and $0.2 \mu \mathrm{m}$ Anodisc filters, the accumulated VLP on the latter were more than 4 times higher than on the former. Not only the pore size but also the material of the filter strongly affect the abundance of VLP observed on the membrane filter. Aluminosilicate Anodisc filters adsorb VLP much more strongly than polycarbonate Poretics filters. The higher intensity of the background fluorescence of the $0.02 \mu \mathrm{m}$ Anodisc filter was observed, which decreased the VLP abundance obtained by this filter to a lower value than that obtained by the $0.2 \mu \mathrm{m}$ Anodisc filter The background fluorescence of the $0.02 \mu \mathrm{m}$ Anodisc filter could not be reduced even by prestaining the filter with Irgalan Black.

\section{Comparison of ELM and TEM methods}

The ratio of the abundance of VLP to that of BLP obtained by the ELM method was compared with the ratio obtained by the TEM method for 4 samples collected from 0,50, 2000 and $5000 \mathrm{~m}$ depth at Stn $\mathrm{A}$ (Table 2). The BLP abundance was highest at the surface and decreased with depth. The VLP/BLP ratios

Table 2. Abundance of viruses and bacterla and their ratios at $\operatorname{Stn} A$

\begin{tabular}{|c|c|c|c|c|}
\hline \multirow{2}{*}{$\begin{array}{l}\text { Depth } \\
\text { (m) }\end{array}$} & \multicolumn{3}{|c|}{ ELM $^{*}$} & \multirow{2}{*}{$\begin{array}{c}\text { TEM } \\
\text { Viruses/ } \\
\text { bacteria }\end{array}$} \\
\hline & $\begin{array}{c}\text { Bacteria } \\
\left(\times 10^{5} \mathrm{ml}^{-1}\right)\end{array}$ & $\begin{array}{c}\text { Viruses } \\
\left(\times 10^{5} \mathrm{ml}^{-1}\right)\end{array}$ & $\begin{array}{l}\text { Viruses } \\
\text { bacteria }\end{array}$ & \\
\hline 0 & 9.4 & 21.0 & 2.23 & 2.08 \\
\hline 50 & 5.1 & 38.2 & 7.49 & 5.00 \\
\hline 2000 & 1.1 & 4.9 & 4.45 & 3.03 \\
\hline 5000 & 0.38 & 0.62 & 1.63 & 1.30 \\
\hline
\end{tabular}

obtained from the ELM method were well correlated with the ratios from the TEM method $\left(r^{2}=0.99\right)$. The comparison indicates that the film count method with the $0.015 \mu \mathrm{m}$ filter gave accurate VLP/BLP ratios.

\section{Size distribution of DNA particles}

Size spectra of DNA particles at 6 different water depths $(0,20,50,200,2000$ and $5000 \mathrm{~m})$ at Stns $A$ and $B$ (subarctic and subtropical stations, respectively) are presented in Fig. 1. Fluorescing particles smaller than $0.2 \mu \mathrm{m}$ (i.e. virus-size VLP) comprise the dominant peak in every sample. Among the fluorescing particles larger than $0.2 \mu \mathrm{m}$ (i.e. bacterium-size BLP), 2 types of size distribution were distinguished from the spectra obtained from Stn A. One type, a clear peak at a size range from 0.2 to $0.3 \mu \mathrm{m}$, was found from the 2000 and $5000 \mathrm{~m}$ samples. The other type, an indistinct peak at size ranges from 0.3 to $0.9 \mu \mathrm{m}$, was observed in samples from 0,20,50 and $200 \mathrm{~m}$ depths. Among the samples with the latter type of spectrum, an indistinct peak of particle numbers in the size range from 0.2 to $0.3 \mu \mathrm{m}$ was observed at 0 and $50 \mathrm{~m}$ depths.

At $\operatorname{Stn}$ B, unimodal and bimodal distributions of BLP were found (Fig. 1). Samples collected from the 0, 20 and $200 \mathrm{~m}$ layers showed clear bimodal peaks for particles $0.3-0.5,0.5-0.7$ and $0.7-0.9 \mu \mathrm{m}$ in size, respectively, in addition to a prominent peak at less than 0.2 $\mu \mathrm{m}$ in size. The TEM method indicated that bacteria with a relatively narrow size range $(0.5-0.6 \mu \mathrm{m})$ were abundant in these samples (data not shown). The unimodal spectrum with a clear peak of BLP less than 0.2 $\mu \mathrm{m}$ in size was found from samples collected at 50 , 2000 and $5000 \mathrm{~m}$. Using the TEM method, the majority of bacteria ranged from 0.2 to $0.3 \mu \mathrm{m}$ in these samples (data not shown)

\section{Vertical distributions of BLP and VLP abundances}

$$
\text { Subarctic station }(\operatorname{Stn} \mathrm{A})
$$

BLP densities were highest at the surface $\left(10 \times 10^{5}\right.$ cells $\mathrm{ml}^{-1}$, and they decreased with depth to $0.4-0.6 \times$ $10^{5}$ cells $\mathrm{ml}^{-1}$ at a depth of $5000 \mathrm{~m}$ (Fig. 2a). Three small BLP peaks were found at the depths of 30,500 and $2000 \mathrm{~m}$. VLP densities were also high in the surface water and decreased with depth, with some variations. Four sharp peaks were found at the depths of $11,50,500$ and $2000 \mathrm{~m}$. The maximum density, $38.1 \times$ $10^{5} \mathrm{ml}^{-1}$, was found at $50 \mathrm{~m}$. The peak VLP densities were coincident with those of BLP in the intermediate and deep waters (500 and $2000 \mathrm{~m}$ depths). Both VLP and BLP density tended to decrease exponen- 

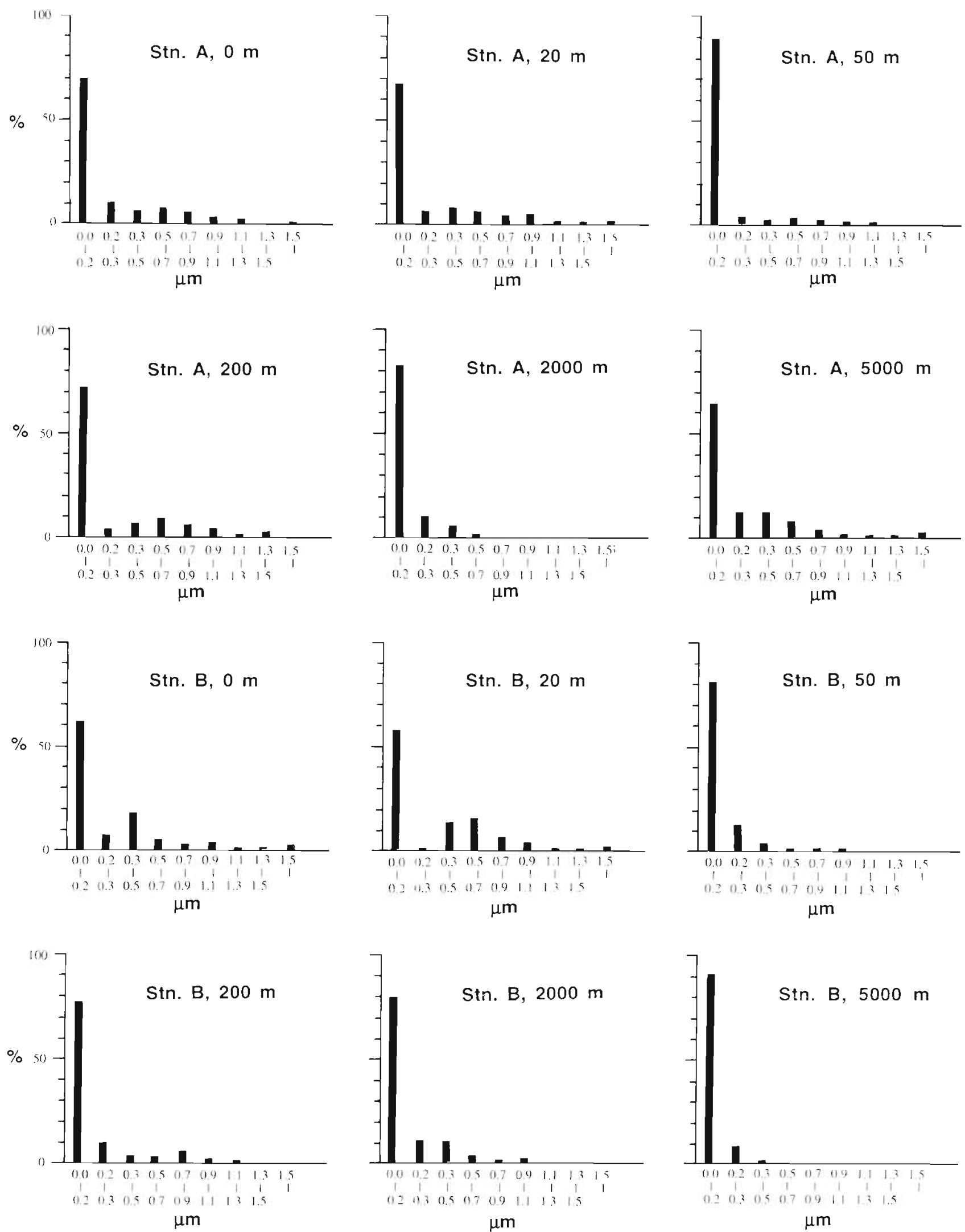

Fig. 1. Size distributions of bacteria (DNA particles larger than $0.2 \mu \mathrm{m}$ ) and viruses (DNA particles smaller than $0.2 \mu \mathrm{m}$ ) at different depths at Strns A and B 
tially with depth. The correlation between depth and VLP density was:

$$
\ln \left(N_{\mathrm{s}}\right)=\ln \left(37.5 \times 10^{5}\right)-0.425 \ln (D) \quad(\mathrm{r}=-0.825)
$$

where $N_{s}$ is abundance of of VLP and $D$ is depth. The correlation between depth and BLP density was:

$$
\ln \left(N_{1}\right)=\ln \left(19.0 \times 10^{5}\right)-0.4355 \ln (D) \quad(\mathrm{r}=-0.928)
$$

where $N_{1}$ is abundance of BLP.

The approximate ratio of VLP to BLP was 2:1 (range 1.1 to 4.5$)$ throughout the entire water column except for the notably large ratio of $7.4: 1$ at the $50 \mathrm{~m}$ layer (Fig 2c).

\section{Subtropical station (Stn B)}

The number of BLP was $2.0 \times 10^{5} \mathrm{ml}^{-1}$ at the sea surface and increased moderately with depth. BLP densities were between 4.0 and $5.3 \times 10^{5} \mathrm{ml}^{-1}$ at 10 to $50 \mathrm{~m}$ depth. The number of BLP decreased with depth below $30 \mathrm{~m}$ and then stabilized at a density of approximately $1 \times 10^{5} \mathrm{ml}^{-1}$ below a depth of $200 \mathrm{~m}$. In contrast, the vertical profile of VLP displays 2 clear peaks of $18.7 \times 10^{5}$ and $11.8 \times 10^{5} \mathrm{ml}^{-1}$ at 50 and $150 \mathrm{~m}$. Below a depth of $400 \mathrm{~m}$, the levels of VLP remained primarily constant, ca $4 \times 10^{5} \mathrm{ml}^{-1}$. Peak VLP densities were not related to those of BLP (Fig 2b). VLP to BLP tended to increase gradually with depth. Two modest peaks were observed for depths of 50 and
Although there was some fluctuation, the ratio of

$150 \mathrm{~m}$. The maximum ratio of $8.7: 1$ was observed for the $5000 \mathrm{~m}$ layer (Fig. 2c).

Smaller BLP, from 0.2 to $0.3 \mu \mathrm{m}$ in size, were pronounced at depths where the VLP/BLP ratios were higher than 4:1 This corresponded to depths of 50 and $2000 \mathrm{~m}$ at Stn $\mathrm{A}$ and of 50,200 and $5000 \mathrm{~m}$ at Stn B (Fig. 2)

\section{DISCUSSION}

In this report, the DAPI-stained particles were classified into 2 categories, smaller or larger than $0.2 \mu \mathrm{m}$ in diameter (Hara et al, 1991). Two problems can be caused by using this size classification to distinguish between bacteria and viruses. One is that the size of the fluorescing particles measured with the images printed on the photographs does not always indicate the accurate sizes of the particles because the halos printed around the light spots obscure the margin of the spots (Lee \& Fuhrman 1987). The other is the size range of the actual bacteria and viruses.

The particles on the fluorescent photomicrographs have halos, and the measured size on the photomicrographs thus tends to be an overestimation. However, the abundance of BLP counted with filters of different pore sizes showed no significant difference (Table 1), indicating that the halo of the fluorescent particles did not cause a large error for measuring VLP and BLP in our procedure.

Viruses with capsid diameter less than

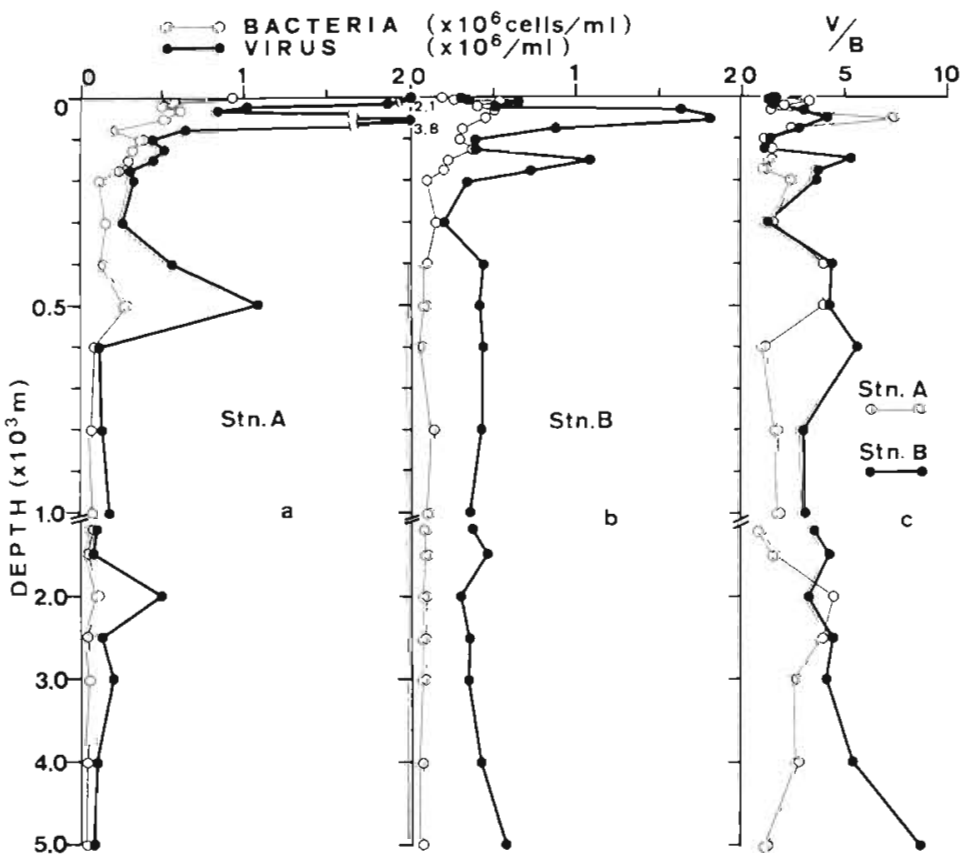

Fig. 2. Vertical distributions of bacteria and viruses at (a) Stn $A$ and at (b) Stn B, and (c) viruses/bacterıa ratios at Stns $A$ and $B$ $0.1 \mu \mathrm{m}$ occupied $68.5 \pm 29.4 \%(n=4)$ of the virus populations observed from the samples collected at $0,50,2000$ and $5000 \mathrm{~m}$ depths at Stn A. The maximum diameter of the capsid observed was $140 \mu \mathrm{m}$ (data not shown) Viruses with capsid diameters less than $0.1 \mu \mathrm{m}$ dominated the virus populations collected from various environments (Wommack et al. 1992, Børsheim 1993, Cochlan et al. 1993, Weinbauer et al. 1993, Weinbauer \& Peduzzi 1994, Maranger \& Bird 1995) The majority of the viruses in the ocean may be smaller than $0.1 \mu \mathrm{m}$ in capsid diameter The majority of the VLP measured in this report were about $0.1 \mu \mathrm{m}$ in diameter. This indicates that the halo produced around the VLP did not cause a large error for measuring VLP in our procedure, and the operational definition of VLP adopted in this report did not contradict the identification of virus particles in epifluorescent microscopy.

Ultramicrobacteria, passing through a $0.2 \mu \mathrm{m}$ polycarbonate membrane filter, are 
common members of the bacterial population in natural marine waters (MacDonell \& Hood 1982). Viruses with a capsid diameter as large as $0.2 \mu \mathrm{m}$ were observed occasionally in California (USA) waters (Cochlan et al. 1993). These ultramicrobacteria and large viruses cannot be distinguished from the printed image of epifluorescent micrography, and will be misclassified in our category of VLP or BLP. However, ultramicrobacteria-sized viruses with icosahedral heads or other geometric characteristics can be distinguished from ultramicrobacteria with TEM. Indeed the slightly larger ratio of virus/bacteria in epifluorescent microscopy compared to the VLP/BLP ratio in electron microscopy (Table 2) implies the existence of ultramicrobacteria in the sample collected from Stn A. The basic corrspondence of the virus/bacteria ratio and VLP/BLP ratio between epifluorescent microscopy and TEM (Table 2), however, indicates that these cells are in the minority.

The total size spectra of the fluorescing particles including the range from $<0.2$ to $1.5 \mu \mathrm{m}$ are shown in Fig. 1. All parts of Fig 1 indicate the discontinuous and prominent dominance of fluorescing particles smaller than $0.2 \mu \mathrm{m}$. The samples collected from 20 and $200 \mathrm{~m}$ depth at Stn A and from 0 and $20 \mathrm{~m}$ depth at Stn B indicate the other obvious peaks located at a length in the range of 0.3 to $0.7 \mu \mathrm{m}$ (Fig 1.). It becomes clear that the smaller particles, corresponding to the VLP fraction, do not exceed $0.2 \mu \mathrm{m}$ in measured size when the size spectra of BLP are shifted to the larger than $0.3 \mu \mathrm{m}$ fraction. DAPI is not a DNA-specific fluorochrome, it will also stain bacterial cell walls (Zweifel \& Hagström 1995). The VLP counts in our criteria may contain a fraction of small detritus. The difference in the virus/ bacteria ratio and VLP/BLP ratio between the TEM and epifluorescent microscopy (Table 2) was less than a factor of 2. This, however, indicates that the majority of VLP measured with epifluorescent microscopy can be attributed to viruses.

Smaller bacteria could pass through the $0.2 \mu \mathrm{m}$ pore sized filter, although gentle filtration methods were employed (Li 1990; Stockner et al. 1990). Measurement artifacts are minimal here as is evidenced by the failure to find a significant difference in bacteria counts between $0.2 \mu \mathrm{m}$ and $0.02 \mu \mathrm{m}$ Anodisc aluminosilicate membrane filters. There was also no significant difference in counts between $0.2 \mu \mathrm{m}$ Poretics and $0.015 \mu \mathrm{m}$ Nuclepore polycarbonate membrane filters. Significant differences were, however, observed when measurements using $0.2 \mu \mathrm{m}$ Anodisc and $0.2 \mu \mathrm{m}$ Poretics filters were compared. The Anodisc filters produced counts up to $30 \%$ higher than those obtained with Poretics or Nuclepore filters. The cause of this difference cannot be attributed to smaller bacteria which might pass through large holes in $0.2 \mu \mathrm{m}$ polycarbon- ate Poretics filters ( $\mathrm{Li}$ 1990, Stockner et al. 1990) because of the similar counts obtained using $0.015 \mu \mathrm{m}$ Nuclepore filters. The difference of flatness between the aluminosilicate membrane filters (Anodisc) compared to the polycarbonate membrane filters (Poretics and/or Nuclepore) revealed under a microscopic examination provides a more satisfactory explanation of the results. An aluminosilicate membrane filter such as Anodisc has a flat surface. This produces a wider filter area of observation with a sharper focus than the polycarbonate filters. The latter produce a faint undulation after mounting on a glass slide with immersion oil and have a smaller filter area of observation with a sharp focus. In observations with Poretics and/or Nuclepore filters, small bacteria located outside of the focused area are easily obscured even if larger bacteria in the same area can be clearly observed. Thus, counts obtained using polycarbonate filters may be underestimated by up to $30 \%$.

There are differences in the patterns of depth profiles of BLP and VLP from the 2 locations investigated in this study. Higher levels in surface water and exponential decreases with depth observed at the subarctic station ( $\operatorname{Stn} \mathrm{A}$ ), indicate that bacteria and virus densities were closely related to other biological activity of the surface water habitat. At the subtropical station (Stn B), both counts were lower at the surface which suggests light inhibition of neustonic bacterial and viral activity (Murray \& Jackson 1993). By way of contrast, in the intermediate and deep waters at Stn $B$, the counts of BLP and VLP were larger than those measured at Stn A. At Stn B, the highest value of the VLP/ $B L P$ ratio was found at the deepest layer $(5008 \mathrm{~m}$ depthi.

Regarding the vertical distribution of VLP and BLP at the 2 stations, we noticed several similarities despite the fact that the 2 stations are located in different ocean domains. One similarity is that the concentrations of VLP and BLP were constant at a depth greater than $200 \mathrm{~m}$ except for the periodic increase of VLP at 500 and $2000 \mathrm{~m}$ depth at Stn A. The VLP/BLP ratios also fluctuated throughout the water columns at both Stns $A$ and $B$ by a factor of 10 .

The next similarity was that the maximum chlorophyli layers found at $20 \mathrm{~m}$ at Stn $\mathrm{A}$ and at $100 \mathrm{~m}$ at Stn. B do not correspond to the depths at which BLP and/or VLP counts were at maximum $(0$ and $50 \mathrm{~m}$ at Stn $A, 20-50$ and $125-150 \mathrm{~m}$ at Stn B). VLP counts peaked at the depths just above and below the depth where chl a was at a maximum. It has been suggested that viruses may play an important role in determining the mortality of prokaryotes (Proctor \& Fuhrman 1990). It also has been suggested that some viruses infect eukaryotes, such as microalgae (Bergh et al. 1989), and viral abundance was positively correlated with chl a 
Table 3. Linear correlation coefficients of virus abundance, bacteria abundance, and chlorophyll a concentration in the upper $200 \mathrm{~m}$ layer at Stns A and B

\begin{tabular}{|c|c|c|c|}
\hline & Viruses & Bacteria & Chl a \\
\hline \multicolumn{4}{|l|}{$\sin A$} \\
\hline Viruses & 1 & & \\
\hline Bacteria & 0.584 & 1 & \\
\hline Chl a & 0.413 & 0.828 & 1 \\
\hline \multicolumn{4}{|l|}{$S \operatorname{tn} B$} \\
\hline Viruses & 1 & & \\
\hline Bacterla & 0.503 & 1 & \\
\hline Chl a & 0.0543 & 0.151 & 1 \\
\hline
\end{tabular}

concentration in water samples taken from surface waters in Tampa Bay, Florida, USA (Jiang \& Paul 1994). The linear correlation coefficients between VLP counts, BLP counts, and chl a concentrations in the upper $200 \mathrm{~m}$ at both stations are indicated in Table 3. VLP abundance was positively correlated with BLP abundance, a correlation which was higher than that with chl a concentration $(r=0.584$ vs $r=0.413$ at Stn $A$, and $r=0.503$ vs $r=0.0543$ at $\operatorname{Stn} B$ ). The linear correlation coefficients between VLP and BLP abundances could be observed throughout the water column, and the coefficients at Stns A and B were $r=0.733(p<$ $0.0001)$ and $r=0.625(p<0.001)$, respectively. The positive correlations between viral abundance and chl $a$ concentration and bacterial abundance were reported from the allopatric samples with a wide range of chl a concentration $\left(0.03\right.$ to $>10 \mu \mathrm{g} \mathrm{l}^{-1}$, from Fig. $10 \mathrm{in}$ Maranger \& Bird 1995), however the correlation could not be seen in sympatric samples collected simultaneously with a narrower chl a concentration range 10.002 to $0.263 \mathrm{\mu g} \mathrm{l}^{-1}$, this study). This implies that chl a concentration has not a direct but an indirect influence on the viral populations. These results suggests that the dominant fraction of viruses in the ocean are not antiphytoplankton viruses, but may be bacteriophages (Wommack et al. 1992).

The other similarity is that the ratio of VLP to BLP is higher when the proportion of the smaller BLP is larger, as observed at 50 and $2000 \mathrm{~m}$ at Stn $\mathrm{A}$ and at 50 and $5000 \mathrm{~m}$ at Stn $\mathrm{B}$ (Figs. 1 \& 2). At depths greater than $200 \mathrm{~m}$, the BLP density was less than $10^{5} \mathrm{ml}^{-1}$. This is less than the minimum density of the food particles required to support phagotrophic protists (Fenchel 1980. 1982a, b). Phagotrophic activity by heterotrophic protists on free living bacteria is unlikely to take place at lower depths. A viral infection could be one factor contributing to the presence of smaller bacteria in circumstances where higher viruses/bacteria ratios were found at deeper depths. To verify this hypothesis, the relationship between viral infection and bacteria size was examined using a simple geometric collision model. Bacteria and virus particles are assumed to move according to the principle of Brownian motion. The effects of turbulent shear and linear translation (through swimming) are ignored and it is assumed that the theory of colloidal aggregation can be applied to the agglutination of bacterial and viral particles. The flux $\left(J_{B V}\right)$ of aggregated bacteria and viruses is calculated using the following formula (Chandrasekhar 1943, Stent 1963):

$$
J_{\mathrm{BV}}=2\left(D_{\mathrm{B}}+D_{\mathrm{V}}\right)\left(R_{\mathrm{B}}+R_{\mathrm{V}}\right) B^{\cdot} \cdot V \cdot
$$

where $D_{\mathrm{B}}$ is coefficient of diffusion of bacteria, $D_{\mathrm{Y}}$ is coefficient of diffusion of virus, $R_{\mathrm{B}}$ is radius of bacteria, $R_{V}$ is radius of virus, $B^{*}$ is equilibrium density of bacteria, and $V^{*}$ is equilibrium density of virus.

It is assumed that $B^{*}$ and $V^{\bullet}$ are constant, and that $J_{B V}$ depends on the radii of bacteria and viruses. It is further assumed that $R_{V}$ is constant, $R_{\mathrm{B} 1}=n R_{V}$, and $R_{\mathrm{B} 2}=a^{-1} R_{\mathrm{B} 1}$. In other words, bacteria $\mathrm{B} 1$ is $n$ times larger than the corresponding viruses and $\mathrm{B} 1$ is a times as large as bacteria B2. Since bacteria are generally larger than viruses, then $n>a$, with $a>1$. The difference between $J_{\mathrm{B} 1 \mathrm{~V}}$ and $J_{\mathrm{B} 2 \mathrm{~V}}$ is expressed as:

$$
J_{\mathrm{BIV}}-J_{\mathrm{L} X \mathrm{~V}}=k(a-1)\left(n^{2}-a\right)>0
$$

where $k=2 B^{\cdot} V \cdot D_{\vee} R_{\vee} a^{-1} n^{-1}$, a constant. Thus, $J_{B 1 V}$ is larger than $J_{\mathrm{B} 2 \mathrm{~V}}$. The ratio of $J_{\mathrm{B} 1 \mathrm{~V}}$ to $J_{\mathrm{B} 2 \mathrm{~V}}$ is given by $J_{B 1 V} / J_{B 2 V}=(a-n)^{2} /\left[a(n+1)^{2}\right]$. This means the smaller the bacterial size, the smaller the flux of aggregated bacteria and viruses.

A viral attack on bacteria cannot be excluded as a source of possible stress leading to a size reduction of bacteria in deep waters with lower bacterial density. As a result, a passive acclimation process involving viruses may reduce both viral densities and the size of bacteria at greater depths. This model may not be applicable to the size determination of free-living bacteria in surface waters. The major stresses which cause the change of size and/or mortality of the bacteria in the surface waters are not only virus infection, but also grazing and a more fluctuating environment (Fenchel 1982a, b, Pace 1988, González et al. 1990, Jiang \& Paul 1994, Wilcox \& Fuhrman 1994)

The discussion of bacterial size has been based on the assumption that the viruses found in deep waters are produced in situ. However, viruses in the surface water are also a potential source of viruses found at greater depths. This can be discussed in terms of 3 possible vertical transport mechanisms, i.e. direct sinking, sinking with fecal pellets, and an aggregation-sedimentation system.

Direct sinking of viral particles from surface waters to great depths is unlikely because Brownian motion is the dominant motion for small viruses which do not 
sink by themselves except when transported as part of the vertical movement of a water mass

Except for incidental ingestion, zooplankters do not consume viruses directly, because of their small size (González \& Suttle 1993). A considerable part of the procaryotic plankters in the ocean could be infected by viruses (Proctor \& Fuhrman 1990). Virus particles multiplying in the cells of these procaryotes could be ingested by bacteriophagous organisms, e.g flagellates and/or ciliates. The excreta from these bacteriophagous organisms are smaller than the organisms themselves or even smaller than the prey procaryotic cells (Koike unpubl. data), and may sink slowly. The excreta from bacteriophagous flagellates and/or ciliates are unlikely to be a major source of viruses at depth.

Viruses have been found in many different phytoplankton forms (Bratbak et al. 1990, 1993, Cottrell \& Suttle 1991) as well as the bacteria and eucaryotes attached to suspended and sinking particles (Proctor \& Fuhrman 1991). Viruses inside and attaching to eucaryotic cells and particles could be a potential food for phytoplankton and detritus feeders producing fecal pellets with a rapid sinking rate in surface waters (Proctor \& Fuhrman 1991). These sinking particles could be a possible source of viruses from the surface to depth especially during periods of algal blooms (Bratbak et al. 1990, 1993). The viruses ingested by such zooplankters might be partially damaged during the digesting process. However, to date, no proper evidence for the abundance of virus-infected alga and/or fecal pellets containing viruses at a depth below $200 \mathrm{~m}$ has been reported.

A possibility is an aggregation-sedimentation system. Small viral particles as well as virus-infected procaryotic and eucaryotic cells can associate with other particles to produce larger particles (Wells \& Goldberg 1993, Kepkay 1994). These microaggregates can then coalesce on a large scale to produce macroaggregates (Kepkay 1994) or be grazed upon by detritus feeders to be excreted as fecal pellets, which have a sinking rate high enough to ensure that significant numbers of viruses make it from the surface to lower depths (Proctor \& Fuhrman 1991) To date, this hypothesis bas not been adequately investigated as a mechanism allowing the transport of viral particles to lower ocean depths.

Within the physical transportation process, biological factors should be explored to account for virus populations at lower depths. Viruses near the surface are species specific (Børsheim 1993). It is safe to assume that the species composition of bacteria at depth is different from that in the surface. Even if a transport system occurs, the differences in bacteria species produce a difficulty for alien viruses transported from the surface to a given depth to attack an appropriate free liv- ing cell in the bacteria found at depth. These viruses may rather be attacked and digested by incompatible bacteria living at depth.

A final hypothesis introduced here for the source of viruses found in deep water is in situ production at depth. The total numbers of bacteria and viruses in deep water are about 10000 and $100000 \mathrm{ml}^{-1}$, respectively (Fig. 2). This level of bacterial and viral densities may be the minimum for bacteriophage replication (Wiggins \& Alexander 1985) or an equilibrium of bacterial and viral densities (Kokjohn et al. 1991), suggesting the viral regulation of bacteria concentration at depth. The bacteria in marine ecosystems are attacked not only by virulent phages, but also by a temperate phage (Freifelder 1987, Jiang \& Paul 1994, Wilcox \& Fuhrman 1994). Reproduced viruses from a lysogenic bacterial host cell could account for the possible production of viruses in deep waters

Distributions in the abundance of organisms are controlled by both production and loss mechanisms. We report here a higher abundance of viruses at depth at Stn B compared to that at Stn A, which implies higher production (or transportation) and/or lower loss of virus at depth at Stn $B$. The loss of viruses in the depths of the ocean should be low because of the lower temperature, the darkness (Murray \& Jackson 1993), and the lower densities of any attacker of viruses (González \& Suttle 1993). However, we have no evidence of the consuming and producing mechanism of viruses at depth. Intensive study on the biodynamics of the abyssal ecosystem is necessary to elucidate the production and loss mechanisms of bacteria and viruses at depth.

Recently, Tanoue (1995) discovered that the majority of dissolved protein components in sea water, at the same 2 locations as the present study as well as other oceanic regions, is due to a membrane protein of a Gram-negative bacterium. The reproduction process of viruses results in the simultaneous release of virus particles and bacterial cell membrane proteins from the virus infected bacteria. The ubiquitous and abundant distribution of viruses as well as bacterial cell membrane protein throughout the water column is consistent with the present study and that of Tanoue (1995) and Tanoue et al. (1995).

Acknowledgements. The authors thank Dr J. Kieley (Miyazaki International College) and Dr T. R. Parsons (University of Britısh Columbia) for reading the manuscrupt and Dr $K$. Mlyake (Mlyazaki International College) for the statistics advice. The authors gratefully acknowledge the captain, officers and crew of the RV 'Hakuho Maru', and the scientists for their help and cooperation during cruise $\mathrm{KH}-91-3$ conducted by the Ocean Research Institute, University of Tokyo. Partial support for this study was provided by a Grant-in-Aid for Sc1ence Research from the Ministry of Education, Science and Culture of Japan (no. 03248105). 


\section{LITERATURE CITED}

Bergh O, Borsheim KY, Bratbak G, Heldal M (1989) High abundance of viruses found in aquatic environments. Nature 340:467-468

Børsheim KY (1993) Native marine bacteriophages. FEMS Microb Ecol 102:141-159

Bratbak G, Egge JK, Heldal M (1993) Viral mortality of the marine alga Emiliania huxleyl (Haptophyceae) and termination of algal blooms. Mar Ecol Prog Ser 93:39-48

Bratbak G. Heldal M, Norland S. Thingstad TF (1990) Viruses as partners in spring bloom microbial trophodynamics. Appl Environ Microbiol 56:1400-1405

Bratbak G, Heldal M. Thingstad TF, Riemann B, Haslund OH (1992) Incorporation of viruses into the budget of microbial C-transfer. A first approach. Mar Ecol Prog Ser 83: $273-280$

Chandrasekhar S (1943) Stochastic problem in physics and astronomy. Rev Mod Physics 15:1-89

Cochlan WP, Wikner J, Steward GF, Smith DC, Azam F (1993) Spatial distribution of viruses, bacteria and chlorophyll a in neritic, oceanic and estuarine environments. Mar Ecol Prog Ser 92:77-87

Cottrell MT, Suttle CA (1991) Wide-spread occurrence and clonal variation in viruses which cause lysis of a cosmopolitan, eukaryotic marine phytoplankton Micromonas pusilla. Mar Ecol Prog Ser 78:1-9

Fenchel $T$ (1980) Suspension feeding in ciliated protozoa: functional response and particle size selection. Microb Ecol 6:1-11

Fenchel T (1982a) Ecology of heterotrophic microflagellates. II. Bioenergetics and growth. Mar Ecol Prog Ser 8:225-231

Fenchel T (1982b) Ecology of heterotrophic microflagellates. IV. Quantitative occurrence and importance as bacterial consumers. Mar Ecol Prog Ser 9:35-42

Freifelder G (1987) Microbial genetics. Jones and Bartlett Publishers, Boston

González JM, Sherr EB, Sherr BF (1990) Size-selective grazing on bacteria by natural assemblages of estuarine flagellates and ciliates. Appl Environ Microbiol 56:583-589

González JM, Suttle CA (1993) Grazing by marine nanoflagellates on viruses and virus-sized particles: ingestion and digestion. Mar Ecol Prog Ser 94:1-10

Hara S, Terauchi K, Koike I (1991) Abundance of viruses in marine waters: assessment by epifluorescence and transmission electron microscopy. Appl Environ Microbiol 57 : $2731-2734$

Jiang SC, Paul JH (1994) Seasonal and diel abundance of viruses and occurrence of lysogenyl/bacteriocinogenyl in the marine environment. Mar Ecol Prog Ser 104:163-172

Kepkay PE (1994) Particle aggregation and the biological reactivity of colloids. Mar Ecol Prog Ser 109:293-304

Kokjohn TA, Sayler GS, Miller RV (1991) Attachment and replication of Pseudomonas aeruginosa bacteriophages under conditions simulating aquatic environments. J Gen Microbiol 137:661-666

Lee S, Fuhrman JA (1987) Relationship between biovolume and biomass of naturelly derived marine bacterioplankton. Appl Environ Microbiol 53:1298-1303

Li WKW (1990) Particles in 'particle-free' seawater: growth of uitraplankton and implications for dilution experiments. Can J Fish Aquat Sci 47:1258-1268

MacDonell MT, Hood MA (1982) Isolation and characteriza-

This article was submitted to the editor tion of ultramicrobacteria from a Gulf Coast estuary. App] Environ Microbiol 43:566-571

Maranger R, Burd DF (1995) Viral abundance in aquatic systems: a comparison between marine and fresh water. Mar Ecol Prog Ser 121:217-226

Murray AG, Eldridge PM (1994) Marine viral ecology: incorporation of bacteriophage into the microbial planktonic food web paradigm. J Plankton Res 16:627-641

Murray AG, Jackson GA (1993) Viral dynamics II: a model of the interaction of ultraviolet light and mixing processes on virus survival in seawater. Mar Ecol Prog Ser 102:105-114

Pace ML (1988) Bacterual mortality and the fate of bacterial production. Hydrobiologia 159:41-49

Patterson DJ, Nygaard K. Steiberg G, Turley CM (1993) Heterotrophic flagellates and other protists associated with oceanic detritus throughout the water column in the middle North Atlantic. J Mar Biol Ass UK 73:67-95

Porter KG, Feig YS (1980) The use of DAPI for identifying and counting aquatic microflora. Limnol Oceanogr 25:943-948

Proctor LM, Fuhrman JA (1990) Viral mortality of marine bacteria and cyanobacteria. Nature 343:60-62

Practor LM, Fuhrman JA (1991) Roles of viral infection in organic particle flux. Mar Ecol Prog Ser 69:133-142

Sieracki ME, Viles CL (1992) Distributions and fluorochromestaining properties of sub-micrometer particles and bacterra in the North Atlantic. Deep Sea Res 39:1919-1929

Stent GS (1963) Molecular biology of bacterial viruses. WH Freeman \& Co, San Francisco

Stockner JG, Kut ME, Cochlan WP (1990) Leaky filters: a warning to aquatic ecologists. Can J Fish Aquat Sci 47:16-23

Suttle CA, Chan AM, Cottrell MT (1990) Infection of phytoplankton by viruses and reduction of primary productivity. Nature 347:467-469

Tanoue E (1995) Detecton of dissolved protein molecules in oceanic waters. Mar Chem 51:239-252

Tanoue E, Nishiyama S, Kamo M. Tsugita A (1995) Bacterial membranes: possible source of a major dissolved protein in seawater, Geochim Cosmochim Acta 59:2643-2648

Turley CM, Mackie PJ (1994) Biogeochemical significance of attached and free-living bacteria and the flux of particles in the NE Atlantic ocean. Mar Ecol Prog Ser 115:191-203

Weinbauer MG, Fuks D, Peduzzi P (1993) Distribution of viruses and dissolved DNA along a coastal trophic gradient in the northern Adriatic Sea. Appl Environ Microbiol 59:4074-4082

Weinbauer MG, Peduzzi P (1994) Frequency, size and distribution of bacteriophages in different marine bacteral morphotypes. Mar Ecol Prog Ser 108:11-20

Wells ML, Goldberg ED (1993) Colloid aggregation in seawater. Mar. Chem. 41:353-358

Wiggins BA, Alexander M (1985) Minimum bacterial density for bacteriophage replication: implication for significance of bacteriophage in natural ecosystems. Appl Environ Microbiol 49:19-23

Wilcox RM, Fuhrman JA (1994) Bacterial viruses in coastal seawater: lytic rather than lysogenic production. Mar Ecol Prog Ser 114:35-45

Wommack KE, Hill RT, Kessel M, Russek-Cohen E, Colwell $R R$ (1992) Distribution of viruses in the Chesapeake Bay. Appl Environ Microbiol 58:2965-2970

Zweifel UL, Hagstrom A (1995) Total counts of marine bacteria include a large fraction of non-nucleoid-containing bacteria (ghosts). Appl Environ Microbiol 61:2180-2185

Manuscript first received: January 12, 1996

Revised version accepted: October 23, 1996 